DOI https://doi.org/10.30525/978-9934-588-90-7-71

\title{
ФРАЗЕОЛОГІЧНІ ОДИНИЦІ У МОВІ РЕГІОНАЛЬНИХ ДРУКОВАНИХ ЗМІ
}

\author{
Плеханова Т. М. \\ кандидат філологічних наук, доцент, \\ завідувач кафедри видавничої справи та редагування \\ Запорізький національний університет \\ м. Запоріжжя, Україна
}

Останнім часом поглибився інтерес до вивчення мовних, структурностильових особливостей публіцистики. Дослідженню специфіки мови та стилю засобів масової інформації присвячені праці науковців Баранника Д.Х., Ярмоленко Т.С., Коваль А.П., Солганик Г.Я., Пінчук О.Ф., Сербенської О.А. та низка статей. Але засоби стилістичного увиразнення фразеологічних одиниць (ФО) у журналістських текстах, мовностилістичний потенціал стійких виразів у мові друкованих регіональних 3МІ ще не були предметом окремого наукового вивчення, що і зумовило актуальність подальшого дослідження цієї проблеми. Метою цієї наукової розвідки $є$ аналіз трансформацій ФО як цілеспрямованого стилістичного прийому у мові регіональних періодичних видань «Запорізька правда» і «Запорозька Січ» .

Широке використання фразеології становить одну із характерних рис газетної мови. Саме тут особливо виразно виявляються стилістичні можливості творчої переробки усталених зворотів. Одним із різновидів функціонування фразеологізмів у мові сучасної преси $€$ їх трансформація. Під трансформацією розуміємо «стилістичний засіб, який полягає в цілеспрямованому оновленні семантики, модифікації структури традиційних фразеологічних одиниць» [1, с. 8]. Унаслідок трансформації значною мірою руйнується структурно-семантична єдність тієї чи іншої фразеологічної одиниці. Трансформований фразеологізм мову публіцистики робить більш влучною, дотепною; для художньої ж літератури він, крім того, є ще одним із джерел образності. Загалом же, трансформація фразеологізмів є живим процесом, активною тенденцією розвитку мови.

Трансформація ФО - це передусім цілеспрямовані зміни, які стосуються як семантики, так i структури стійких виразів. Вони неодмінно передбачають стилістичну мету, бо випливають із прагнення журналіста органічно поєднати, злити воєдино з контекстом загально- 
відомий вираз, уточнити чи деталізувати значення ФО в зв'язку 3 конкретною ситуацією публіцистичного твору.

Усі способи трансформації ФО зводяться до двох типів - семантичного та структурно-семантичного. До першого типу можна віднести прийом переосмислення фразеологізму без будь-яких змін у його лексико-граматичній структурі та вживання фразеологізму як вільного словосполучення. До різновидів структурно-семантичних трансформацій належать такі стилістичні прийоми: 1) лексична заміна компонентів фразеологізму словами вільного вжитку; 2) поширення фразеологізму; 3) фразеологічний натяк; 4) контамінація фразеологічних одиниць; 5) еліпсис фразеологізму [1, с. 14].

У мові газет трансформація фразеологізмів зустрічається не рідше, ніж у художній літературі, що пояснюється самою специфікою газети, властивостями, за висловом Г.О. Винокура, піі «концентрованої мови». Найчастіше ці можливості фразеології використовуються у газеті для створення містких, яскравих заголовків: «Від вогню не зарікайся» («Запорізька правда» - пор. від суми та від тюрми не зарікайся); «3 дощу ma під зливу» («Запорозька Січ» - пор. з дощу та під ринву).

Аналіз матеріалів запорізьких газет «Запорізька правда» $\mathrm{i}$ «Запорозька Січ» виявив, що фразеологізми та їх структурно-семантичні трансформації використовуються журналістами цих видань доволі часто. На шпальтах газет знаходимо майже усі різновиди структурносемантичних трансформацій стійких сполучень, створені як заміною окремих компонентів ФО словами вільного вжитку, так і відхиленням від звичайної кількості компонентів фразеологічної одиниці.

Прагнення до небуденного, образного, оригінального вираження думки, постійний пошук експресивності часто штовхають авторів на переробку усталених, традиційних фразеологічних виразів. Така переробка завжди є наслідком індивідуальної мовотворчості, а використання фразеологічних одиниць у трансформованому вигляді завжди зумовлюється певними стилістичними завданнями. «Стилістично задане відхилення від фразеологічної норми - один із експресивних засобів (переважно художнього мовлення), окремий випадок породження мовної виразності» [2, с. 117].

Значення стійких зворотів у процесі функціонування може ставати дуже узагальненим і абстрактним. Тому журналісти, намагаючись зробити більш відчутним внутрішній образ, що ліг в основу фразеологізму, і наблизити його зміст до зображуваних явищ, подій, ситуацій, вдаються до заміни одного з компонентів словом або словосполученням, яке семантично співвідносне з текстом твору. У газетних текстах така субституція призводить ще й до конкретизації значення фразеологізму, його пристосування до відповідного контексту Напр.: «У рідніü столищзі й 
стіни допомагають» («Запорізька правда» - пор. вдома ци стіни допомагають); «Від вогню не зарікайся» («Запорізька правда» - пор. від суми та від тюрми не зарікайся); «Езопівській недомовленості не повинно бути місця у нашій пресі» («Запорозька Січ»- пор. езопівська мова).

Інколи заміни компонентного складу фразеологічних одиниць призводять до значних зрушень у семантиці стійких виразів, які набувають протилежного значення: «I собі, і людям» («Запорозька Січ»пор. ні собі ні людям); «Не чекайте сім років» («Запорізька правда» пор. обіияного сім років чекають).

Зміна форми та експресивно-стилістичних якостей відомого фразеологізму здійснюється також завдяки розширенню його новими лексичними компонентами, які диктуються логіко-ситуативними умовами контексту. Напр.: «Сусід там живе.., а самого не видно, мов крізь землю, в Америку провалився» («Запорозька Січ»); «I мишеня без санкції не проскочить» («Запорозька Січ»).

У мові газети прийом розширення чи звуження компонентного складу фразеологізмів проявляється уже в таких мінімальних втручаннях у структуру ФО, як введення заперечних часток, або їх усунення, якщо вони є у складі звороту: мовчання не золото («Запорізька правда»); молодо та не зелено («Запорізька правда»); крапля камінь не точить («Запорозька Січ»).

Значний ефект (наприклад, гумористичний) як у художній мові, так i в газетних текстах дає заміна стилістично нейтрального складника фразеологізму його експресивним синонімом, особливо тоді, коли цей синонім - просторічного або жаргонного походження. Цим майстри слова досягають, можна сказати, подвійного ефекту, бо ж «кожен фразеологізм передає думку набагато виразніше, експресивніше, ніж будь-яка лексема. Коли ж до того ще й у самому фразеологізмі замінюються окремі компоненти словами, які передають тотожне значення з більшою виразовою силою, тоді твориться, так би мовити, експресія в експресії» [1, с. 117]. Напр.: «Скільки брів по калюжах, стільки вертілося в голові: «Чого тебе нечиста сила поперла в це забуте Богом селище?»» («Запорозька Січ»- пор. нечиста сила понесла).

Яскравий стилістичний ефект дає переведення фразеологізму в новий семантичний план завдяки його контамінації з іншим фразеологізмом. У мові газети цей прийом створює враження вільного, буквального вживання слів, своєрідний ефект розкриття внутрішньої форми звороту, напр.: «Розповідають, що мешканці цього міста були свідками того, як серед сонячного дня і прямо з голубого неба на площі $і$ вулиці почали падати срібні монети» («Запорозька Січ»). Автор відштовхується від двох зворотів: серед білого дня і з неба впасти, в першому замінюючи слово білий на сонячний, а до складу другого включає слово голубий. 
У пошуках мовленнєвої експресії та з метою економії мовних засобів і лаконізації мовлення, що $є$ особливо актуальним для мови газет, майстри слова можуть вдаватися й до зміни синтаксичної структури фразеологізму. Найчастіше при цьому використовується еліпсис скорочення компонентного складу ФО, напр.: «Дурні розмови (чого, наприклад, було лізти до Іраку зі своєю «демократією») найліпше «клином» вибивати» («Запорозька Січ» - пор. клин клином вибивають); «Після цих подій великий начальник як у воду...» («Запорозька Січ» пор. як у воду впасти); «Не хлібом же єдиним...» («Запорізька правда»).

Своєрідним та яскравим $є$ образний ряд, який створюють журналісти за допомогою фразеологічного натяку, напр.: «Сім тисяч гривень - сума незначна, вартість справи дорівнює вартості тих самих виїдених яєць» («Запорізька правда» - пор.: справа виїденого яйия не варта); «Дуже мало ще зробила наша влада, щоб не відчували себе пенсіонери тим самим горохом» («Запорозька Січ» - пор. жити, як горох при дорозі); «Тоді виникає доречне запитання: чи ж довго ще ми будемо півнями 3 відомої приказки?» («Запорозька Січ» - пор. наше діло півняче: прокукурікали, а там хоч $і$ не розвидняйся).

Отже, своєрідність використання фразеологічних одиниць у мові сучасної преси полягає насамперед у великій насиченості газетного тексту стійкими виразами, бо газетна мова тяжіє до готових словесних формул. Значна кількість фразеологізмів внаслідок частого використання втрачає свою попередню свіжість і перетворюється в мовний штамп, позбавлений образності, через що й виникає потреба в їх оновленні. Трансформації ФО є свідомим відтворенням внутрішньообразної основи фразеологізму, його розвитком, збагаченням. Вони пов'язані з творчим завданням розширення меж значення $Ф О$, їх експресивно-стилістичного звучання. Трансформ (результат трансформації ФО) завжди неповторний і вважається своєрідним індивідуально-авторським неологізмом.

Зважаючи на досить низький рівень мовної культури багатьох сучасних українських засобів масової інформації, подальше дослідження специфіки уживання ФО та засобів їх увиразнення у газетних публікаціях сприятиме урізноманітненню журналістських текстів, їх образності, експресивності та яскравості.

\section{Література:}

1. Білоноженко В.М., Гнатюк I.C. Функціонування та лексикографічна розробка українських фразеологізмів. Київ : Наук. думка, 1989. $298 \mathrm{c}$.

2. Чабаненко В.А. Стилістика експресивних засобів української мови : монографія. Запоріжжя : ЗДУ, 2002. 351с. 